\title{
Basalts with back-arc MORB affinity from the South Andaman ophiolite Belt, India.
}

\author{
SALIM AKHTAR ${ }^{1}$ ASHIMA SAIKIA ${ }^{2}$
}

${ }^{1}$ Deaprtment of Geology, University of Delhi, Delhi -110007, akhtar14.du@gmail.com

${ }^{2}$ Deaprtment of Geology, University of Delhi, Delhi -110007, ashima.saikia@gmail.com

The Mesozoic South Andaman island ophiolite belt is supposed to be the part of an extension of the Tethyan suture zone located in the south-eastern margin of Indian plate in the Indian Ocean. The present study details the geochemical and mineral chemical characteristics of the pillow and massive basalts of the ophiolite suite. The basalts contain plagioclase ( $\mathrm{Ab}_{39}$ 99), clinopyroxene (En9-52 $\mathrm{WO}_{22-61} \mathrm{Fs}_{7-28}$ ) with trace amounts of magnetite, apatite and Cr-spinel. Geochemically the basaltic sample has $\mathrm{SiO}_{2}$ (42.8149.28 wt \%), $\mathrm{TiO}_{2}$ (0.77- $1.65 \mathrm{wt} \%$ ) and $\mathrm{Mg} \mathrm{\#} \mathrm{value} \mathrm{of}$ 34.89- 63.17. It is tholeiitic in composition with low concentrations of $\mathrm{Na}_{2} \mathrm{O}+\mathrm{K}_{2} \mathrm{O} \quad(0.52-5.26$ wt.\%)The chondrite-normalized rare earth element (REE) patterns of basaltic rocks show LREE $\left[(\mathrm{La} / \mathrm{Sm})_{\mathrm{N}}=0.68\right.$ 1.79] depletion with flat MREE and HREE [(Sm/Yb $)_{N}=$ 0.99 - 1.31]. The basalts show significant enrichment of LILEs such as $\mathrm{Cs}, \mathrm{Rb}, \mathrm{Ba}, \mathrm{U}$, and $\mathrm{Pb}$, and depletion of HFSEs $\mathrm{Nb}, \mathrm{Zr}$, and $\mathrm{Ti}$ in primitive mantle normalized diagram, indicating subduction-related enrichment and are comparable to arc basalts and back-arc basalts. Petrology and geochemical characteristics suggest that these basalts are the product of MORBlike magma derived from a depleted mantle corresponding to $5-20 \%$ partial melting of spinel Iherzolite. Our observations are indicative of intraoceanic subduction setting and suggest that the basalts of South Andaman ophiolite were formed in a back-arc supra-subduction zone and subsequently have been enriched by slab-derived fluids. 